\title{
Adrenomedullin expression in a rat model of acute lung injury induced by hypoxia and LPS
}

Jackeline Ågorreta, Javier J. Zulueta, Luis M. Montuenga and Mercedes Garayoa Am J Physiol Lung Cell Mol Physiol 288:L536-L545, 2005. First published 3 December 2004; doi:10.1152/ajplung.00314.2004

You might find this additional info useful...

This article cites 42 articles, 17 of which can be accessed free at:

http://ajplung.physiology.org/content/288/3/L536.full.html\#ref-list-1

This article has been cited by 4 other HighWire hosted articles

Role of Adrenomedullin in Lyme Disease

Meghan L. Marre, Courtney T. Darcy, Janeth Yinh, Shizuo Akira, Satoshi Uematsu, Allen C.

Steere and Linden T. Hu

IAI, November, 15 2010; 78 (12): 5307-5313.

[Abstract] [Full Text] [PDF]

The Systemic Inflammation of Alveolar Hypoxia Is Initiated by Alveolar

Macrophage-Borne Mediator(s)

Jie Chao, John G. Wood, Victor Gustavo Blanco and Norberto C. Gonzalez

$A J R C M B$, October, 20 2009; 41 (5): 573-582.

[Abstract] [Full Text] [PDF]

\author{
Alveolar macrophages are necessary for the systemic inflammation of acute alveolar \\ hypoxia \\ Norberto C. Gonzalez, Julie Allen, V. Gustavo Blanco, Eric J. Schmidt, Nico van Rooijen and \\ John G. Wood \\ J Appl Physiol, October, 1 2007; 103 (4): 1386-1394. \\ [Abstract] [Full Text] [PDF]
}

Adrenomedullin ameliorates lipopolysaccharide-induced acute lung injury in rats

Takefumi Itoh, Hiroaki Obata, Shinsuke Murakami, Kaoru Hamada, Kenji Kangawa, Hiroshi

Kimura and Noritoshi Nagaya

Am J Physiol Lung Cell Mol Physiol, August, 1 2007; 293 (2): L446-L452.

[Abstract] [Full Text] [PDF]

Updated information and services including high resolution figures, can be found at:

http://ajplung.physiology.org/content/288/3/L536.full.html

Additional material and information about AJP - Lung Cellular and Molecular Physiology can be found at:

http://www.the-aps.org/publications/ajplung

This infomation is current as of February 28, 2011.

AJP - Lung Cellular and Molecular Physiology publishes original research covering the broad scope of molecular, cellular, and integrative aspects of normal and abnormal function of cells and components of the respiratory system. It is published 12 times a year (monthly) by the American Physiological Society, 9650 Rockville Pike, Bethesda MD 20814-3991. Copyright ( 2005 by the American Physiological Society. ISSN: 1040-0605, ESSN: 1522-1504. Visit our website at http://www.the-aps.org/. 


\title{
Adrenomedullin expression in a rat model of acute lung injury induced by
}

\section{hypoxia and LPS}

\author{
Jackeline Agorreta, ${ }^{1,2}$ Javier J. Zulueta, ${ }^{3}$ Luis M. Montuenga,,${ }^{1,2}$ and Mercedes Garayoa ${ }^{1,2}$ \\ ${ }^{1}$ Division of Oncology, Center for Applied Medical Research, University of Navarra; ${ }^{2}$ Department of Histology and \\ Pathology; and ${ }^{3}$ Pulmonary Service, Clínica Universitaria; University of Navarra School of Medicine, Navarra, Spain
}

Submitted 20 August 2004; accepted in final form 23 November 2004

\begin{abstract}
Agorreta, Jackeline, Javier J. Zulueta, Luis M. Montuenga, and Mercedes Garayoa. Adrenomedullin expression in a rat model of acute lung injury induced by hypoxia and LPS. Am J Physiol Lung Cell Mol Physiol 288: L536-L545, 2005. First published December 3, 2004; doi:10.1152/ajplung.00314.2004.—Adrenomedullin (ADM) is upregulated independently by hypoxia and LPS, two key factors in the pathogenesis of acute lung injury (ALI). This study evaluates the expression of ADM in ALI using experimental models combining both stimuli: an in vivo model of rats treated with LPS and acute normobaric hypoxia $\left(9 \% \mathrm{O}_{2}\right)$ and an in vitro model of rat lung cell lines cultured with LPS and exposed to hypoxia $\left(1 \% \mathrm{O}_{2}\right)$. ADM expression was analyzed by in situ hybridization, Northern blot, Western blot, and RIA analyses. In the rat lung, combination of hypoxia and LPS treatments overcomes ADM induction occurring after each treatment alone. With in situ techniques, the synergistic effect of both stimuli mainly correlates with ADM expression in inflammatory cells within blood vessels and, to a lesser extent, to cells in the lung parenchyma and bronchiolar epithelial cells. In the in vitro model, hypoxia and hypoxia + LPS treatments caused a similar strong induction of ADM expression and secretion in epithelial and endothelial cell lines. In alveolar macrophages, however, LPS-induced ADM expression and secretion were further increased by the concomitant exposure to hypoxia, thus paralleling the in vivo response. In conclusion, ADM expression is highly induced in a variety of key lung cell types in this rat model of ALI by combination of hypoxia and LPS, suggesting an essential role for this mediator in this syndrome.
\end{abstract}

acute respiratory distress syndrome; endotoxin; alveolar macrophages; endothelial cells; type II pneumocytes

ACUTE RESPIRATORY DISTRESS SYNDROME (ARDS), the most severe expression of acute lung injury (ALI), is characterized by increased microvascular permeability, severe hypoxemia, and diffuse pulmonary infiltrates (2). Although there are many clinical disorders associated with the development of ARDS, sepsis is the most common cause of this syndrome. ALI/ARDS represent important clinical entities with mortality rates of $40-50 \%$ (30). A recent study estimates an incidence for sepsisassociated ARDS of 45-63 cases per $10^{5}$ persons per year in the USA (10).

Even though LPS treatment induces hypoxemia (via lung injury), classical rodent models of ALI in which large doses of LPS are administered result in higher levels of circulating cytokines than those found in patients with sepsis (14); the animals die from "cytokine storm," often not accurately reflecting clinical developments in human ALI (32). As noted by a National Heart, Lung, and Blood Institute working group on ALI (25), two-hit animal models might better reflect actual

Address for reprint requests and other correspondence: J. Agorreta, Div. of Oncology, Center for Applied Medical Research (CIMA), Pío XII 55, 31008 Pamplona, Spain (E-mail: jagorreta@unav.es). conditions present in patients with ALI. Taking into account that hypoxia and endotoxin are the main factors involved in this syndrome (40), we have developed in vivo and in vitro rat models of ALI combining acute normobaric hypoxia and LPS insult (1).

Several cytokines, such as IL-1, -6, -8, -10, and TNF- $\alpha$ (40), and other mediators, such as nitric oxide (NO) (1), have been found to play a crucial role in the orchestration of the inflammatory response associated with ALI. Adrenomedullin (ADM) is a multifunctional regulatory peptide, and its numerous biological actions support an integrator role in the cellular response to inflammation (7). ADM was originally isolated from a human pheochromocytoma (16) and belongs to the calcitonin family, which includes calcitonin gene-related peptide and amylin. It was initially described for its hypotensive activity and has since been implicated in diverse physiological functions that include bronchodilation, antimicrobial activity, modulation of central brain function, cell growth regulation, survival from apoptosis, and induction of angiogenesis (20). ADM is expressed in a wide variety of organs, including adult and fetal lung, and in several types of cancer also comprising lung cancer $(8,22)$. Hypoxic conditions, most proinflammatory cytokines, and LPS upregulate ADM basal expression in cultured cells $(8,26)$ and in many organs such as lung, heart, and liver $(12,34)$. Furthermore, ADM plasma levels are elevated in patients with lung cancer, asthma, sepsis, chronic obstructive pulmonary disease, and the systemic inflammatory response syndrome (SIRS) (20). Together, these premises suggest that ADM may also play a role in the development of ALI. In an attempt to investigate this hypothesis, as well as to study the effect of hypoxia as an added cofactor to LPS treatment in ALI-reproducing conditions, we have studied the expression of ADM in in vivo and in vitro models of rat ALI. ADM expression has been analyzed by Northern blot, RT-PCR, in situ hybridization (ISH), Western blot, and RIA techniques.

\section{MATERIAL AND METHODS}

\section{Animals and Treatments}

The protocol followed was similar to that applied previously (1). Female 7-wk-old Fischer Harlan rats, weighing 125-200 g, were intraperitoneally injected with saline $(200 \mu \mathrm{l})$ or LPS $(0.1 \mathrm{mg} / \mathrm{kg}$ Escherichia coli O111:B4, phenol extract; Sigma, St. Louis, MO) and immediately exposed to normoxia (room air, $21.8^{\circ} \mathrm{C}$, and relative humidity of $40 \%$; both parameters monitored by datalogger device Tinytag Ultra; Meaco Europa, Ijzendoorn, Netherlands) or normobaric hypoxia $\left(9 \% \mathrm{O}_{2}\right)$ : rats were placed in a $300 \times 350 \times 600-\mathrm{mm}$

The costs of publication of this article were defrayed in part by the payment of page charges. The article must therefore be hereby marked "advertisement" in accordance with 18 U.S.C. Section 1734 solely to indicate this fact. 
Plexiglas chamber specially designed for this project (Martínez Íñigo, Pamplona, Spain) at $22.1^{\circ} \mathrm{C}$, relative humidity of $50.2 \%$, and gassed with a mixture of $9 \% \mathrm{O}_{2}-91 \% \mathrm{~N}_{2}$ at a constant flow throughout the experiment. Oxygen concentration in the chamber was continuously monitored with a microPac oxygen sensor (Drager Sicherheitstechnik). Four groups resulted from these experimental conditions: 1) normoxia group (control): rats subjected to normoxia + saline, 2) hypoxia group: hypoxia + saline, 3) LPS group: normoxia + LPS, and 4) hypoxia + LPS group. Rats were killed by cervical dislocation after $3,6,12$, or $24 \mathrm{~h}$ of treatment. At each time point, four rats were examined in each group $(n=64)$. In the hypoxia + LPS group, all rats survived after 3 or $6 \mathrm{~h}$ of exposure; however, the survival rate after $12 \mathrm{~h}$ was $80 \%$, and the treatment was $100 \%$ lethal after $24 \mathrm{~h}$. The study protocol was approved by the University of Navarra Animal Care and Use Committee (no. 002/99) and conforms to National Institutes of Health guidelines. The lungs were excised, and the left lobes were fixed in buffered formalin for $24 \mathrm{~h}$, dehydrated, and embedded in paraffin. The correspondent right lobes were divided into two portions and frozen in liquid nitrogen for subsequent protein or RNA analyses.

\section{Vascular Permeability to Protein}

Extravasation of intravascular protein was measured with FITClabeled BSA as an estimate parameter of vascular permeability (35). In brief, four animals per group $(n=16)$ were injected with $7 \mathrm{mg} / \mathrm{kg}$ of FITC-BSA in 0.1 M phosphate buffer (PB), $\mathrm{pH} 7.6$, in one of the caudal veins before exposure to each treatment for $6 \mathrm{~h}$. Animals were deeply anesthetized with an intraperitoneally injected mixture of ketamine $(80 \mathrm{mg} / \mathrm{kg})$ and xylazine $(15 \mathrm{mg} / \mathrm{kg})$, the thoracic cavity was opened, and $1 \mathrm{ml}$ of blood was obtained by cardiac puncture and adequately reserved for subsequent serum extraction (centrifugation at $1,430 \mathrm{~g}$ at $4^{\circ} \mathrm{C}$ for $30 \mathrm{~min}$ ). After perfusion of the pulmonary circulation with PB rinsing solution, the lungs were harvested. The accessory lobe was fixed in $4 \%$ buffered formalin for $24 \mathrm{~h}$, dehydrated, and embedded in paraffin; the rest of the lung was weighed, encased in aluminum foil, and frozen in liquid nitrogen. Immunohistochemical techniques for FITC were applied on 4- $\mu$ m-thick paraffin sections of lung tissue. After dewaxing, endogenous peroxidase was inactivated by treatment with $3 \%$ hydrogen peroxide for $15 \mathrm{~min}$, nonspecific background was blocked with normal goat serum (1:20) for $30 \mathrm{~min}$, and the sections were incubated overnight at $4^{\circ} \mathrm{C}$ with the primary monoclonal antibody anti-FITC (Dako, High Wycombe, UK) at a 1:100 dilution. The sections were revealed with the EnVision system (Dako) and were subsequently counterstained with hematoxylin, dehydrated, and mounted in distyrene plasticizer xilene mounting medium (BDH, Poole, UK). On the other hand, frozen lungs were thawed and homogenized in five volumes of PB with a Polytron homogenizer (Kinematica, Steinhofhalde, Switzerland). The homogenate was clarified by centrifugation, and the final protein concentration was determined (BCA kit; Pierce, Rockford, IL). FITC-derived fluorescence (excitation wavelength, $488 \mathrm{~nm}$; emission wavelength, $520 \mathrm{~nm}$ ) was detected using a Polastar Galaxy fluorometer (BMBH Labtechnologies, Offenburg, Germany). The number of fluorescence units present in the supernatant per milligram of protein was calculated both for lung homogenates and serum. These values were transformed with a standard curve obtained by measuring the fluorescence intensity of different dilutions of FITC-BSA in PB and then plotting the amount of FITC-BSA against the number of fluorescence units as a graph (35). The vascular permeability index was determined according to the following ratio expressed as percentage: (ng FITC/mg protein) lung/(ng FITC/mg protein) serum.

\section{Cell Lines and Exposures}

Cell lines in this study were selected to represent the major cell types occurring in the lung. Normal rat lung type II epithelial cells (CCL-149), normal rat alveolar macrophages (CRL-2192), and rat pulmonary microvascular endothelial cells (RPMVEC) were used. CCL-149 and CRL-2192 were purchased from the American Type Tissue Collection (Manassas, VA). RPMVEC were a gift from Dr. Una Ryan (Avant Immunotherapeutics, Needham, MA).

Cell lines were cultured in their specific culturing medium $(\mathrm{F}-12 \mathrm{~K}$ medium for CCL-149 and CRL-2192, and RPMI 1640 for RPMVEC) supplemented with $10 \%$ FCS, $2 \mathrm{mM} \mathrm{L-glutamine,} 100 \mathrm{U} / \mathrm{ml}$ penicillin, and $100 \mu \mathrm{g} / \mathrm{ml}$ streptomycin (all tissue culture reagents purchased from GIBCO BRL-Invitrogen, Barcelona, Spain). Fresh medium was added $12 \mathrm{~h}$ before each experiment.

Treatments in vitro tried to reproduce those used in the in vivo model of rats inhaling $9 \% \mathrm{O}_{2}$. Using the alveolar gas equation and assuming that the respiratory quotient and $\mathrm{Pa}_{\mathrm{CO}_{2}}$ are similar in rodents and humans (17), we find that a $9 \% \mathrm{FI}_{\mathrm{O}_{2}}$ results in an alveolar partial pressure of $\mathrm{O}_{2}\left(\mathrm{~Pa}_{2}\right)$ of $\sim 15 \mathrm{mmHg}$. To achieve this $\mathrm{Pa}_{2}$, the concentration of $\mathrm{O}_{2}$ at a barometric pressure of $760 \mathrm{mmHg}$ should be $\sim 1-2 \%$.

Cell cultures were exposed to $20 \% \mathrm{O}_{2}, 5 \% \mathrm{CO}_{2}, 75 \% \mathrm{~N}_{2}$ (normoxia) or were placed in a humidified airtight incubation chamber (Billups-Rothenberg, Del Mar, CA) and gassed with $1 \% \mathrm{O}_{2}, 5 \% \mathrm{CO}_{2}$, $94 \% \mathrm{~N}_{2}$ (hypoxia). We added LPS $(100 \mathrm{ng} / \mathrm{ml})$ to the cell culture medium just before initiating exposure to normoxia or hypoxia. Similarly to the in vivo model, four experimental groups of cells resulted from combination of these treatments: 1) normoxia, 2) hypoxia, 3) LPS, and 4) hypoxia + LPS. Cells were exposed to each treatment for $0.5,1,3,6,12$, or $24 \mathrm{~h}$. Immediately after the treatment, the conditioned media were recovered, and total RNA or protein was extracted.

\section{Inhibitor Studies}

To test whether ADM was being degraded in the culture medium from the alveolar macrophages cell line (CRL-2192), two additional experiments with protease inhibitor agents ( $5 \mathrm{mM}$ EDTA and $0.5 \mathrm{mM}$ 1,10 phenanthroline, Sigma) were carried out: 1) conditioned media from macrophages exposed to each treatment were incubated with exogenously added ADM $(1.28 \mathrm{ng} / \mathrm{ml})$ for $24 \mathrm{~h}$ at $37^{\circ} \mathrm{C}$ with or without each inhibitor; 2) 1,10 phenanthroline was added to CRL2192 cells subjected to a 24-h treatment. Both protease inhibitors were chosen because of their ability to prevent ADM degradation (19).

\section{Northern Blot}

Northern blot was performed as previously described (8) with slight modifications. Samples of $15 \mu \mathrm{g}$ of total RNA were separated in $1 \%$ agarose gels containing $2.2 \mathrm{M}$ formaldehyde. RNA was then transferred by capillarity to nitrocellulose membranes (Schleicher \& Schuell, Keene, NH), and blots were subjected to UV crosslinking at $120 \mathrm{~J} / \mathrm{cm}^{2}$. The rat ADM cDNA probe used in this study was kindly donated by Dr. Alfredo Martínez (23). cDNA templates were labeled with $\left[\alpha-{ }^{32} \mathrm{P}\right] \mathrm{dCTP}(3,000 \mathrm{Ci} / \mathrm{mmol}$; Amersham Pharmacia Biotech, Buckinghamshire, UK) by random priming, and unincorporated nucleotides were removed using Probe-Quant G-50 Micro columns (Amersham Pharmacia Biotech). Hybridization was carried out overnight at $42^{\circ} \mathrm{C}$ in a hybridization buffer containing $40 \%$ formamide. Autoradiographic signal was detected using XAR Film (Kodak, Rochester, NY). Densitometric analysis of ADM mRNA expression was expressed as the ratio of ADM to ribosomal protein $\mathrm{S} 9 \mathrm{mRNA}$ values.

\section{ISH for Rat ADM}

The protocol followed was similar to that applied previously (1). Sections of formalin-fixed rat lung were deparaffinized, rehydrated, and permeabilized in $0.2 \%$ Triton-PBS for $15 \mathrm{~min}$. After a proteinase $\mathrm{K}(60 \mu \mathrm{g} / \mathrm{ml}$ in $0.1 \mathrm{M}$ Tris-50 $\mathrm{mM}$ EDTA, $\mathrm{pH} 8)$ digestion at $37^{\circ} \mathrm{C}$ for $30 \mathrm{~min}$, the process was stopped in $0.1 \mathrm{M}$ glycine-PBS. Tissue was subsequently acetylated with $0.25 \%$ acetic anhydride in $0.1 \mathrm{M}$ triethanolamine, $\mathrm{pH} 8$, washed in diethyl pyrocarbonate-treated $\mathrm{H}_{2} \mathrm{O}$, and 
air dried at room temperature. A rat ADM 594-bp RT-PCR product containing the ADM peptide-coding region [GenBank NM012715: 5'-AGCCCACATTCGAGTCAAAC-3' (sense, bp 429-448) and 5' TTTCCTCGCTAGGTTTTGGA-3' (antisense, bp 1,003-1,022)] was subcloned into the pCR-II vector (Invitrogen). After plasmid linearization, digoxigenin-labeled riboprobes were synthesized with T7 or SP6 RNA polymerases with a digoxigenin RNA labeling kit (Roche Diagnostics, Mannheim, Germany). Hybridization with the antisense probe $(50 \mathrm{ng} / \mu \mathrm{l})$ was performed overnight at $43^{\circ} \mathrm{C}$ in a moist chamber; hybridization with the sense probe $(50 \mathrm{ng} / \mu \mathrm{l})$ in the same conditions was used as a negative control. After increasingly stringent washes, the slides were treated with RNase A $(20 \mu \mathrm{g} / \mathrm{ml})$ at $37^{\circ} \mathrm{C}$ for $15 \mathrm{~min}$. Sections were incubated for $2 \mathrm{~h}$ with 1:300 antidigoxigenin antibody labeled with alkaline phosphatase (AP) (Roche Diagnostics). Nitroblue tetrazolium chloride and 5-bromo-4-chloro-3-indolyl phosphate (Roche Diagnostics) were used to visualize AP activity. Slides were mounted in 1:1 glycerol-PBS.

\section{RIA for Rat ADM}

Cells were seeded in triplicate and subjected to normoxia, hypoxia, LPS, or hypoxia + LPS treatments for 12,24 , or $48 \mathrm{~h}$. The conditioned media were collected and stored at $-20^{\circ} \mathrm{C}$ with $5 \mathrm{mM}$ EDTA and a protease inhibitor cocktail. Cellular protein concentration per plate was determined to verify similar cell protein content so that ADM in the media could be compared. The concentration of ADM was measured by RIA analysis according to manufacturer's instructions in a commercially available RIA kit for rat ADM (Phoenix Pharmaceuticals, Belmont, CA). In brief, $0.1 \mathrm{ml}$ of conditioned medium (or appropriate dilution of standard ADM) was preincubated for $18 \mathrm{~h}$ at $4^{\circ} \mathrm{C}$ with $0.1 \mathrm{ml}$ of primary antibody against rat ADM. After that, $0.1 \mathrm{ml}$ of ${ }^{125} \mathrm{I}-\mathrm{ADM}$ was added $(10,000 \mathrm{cpm})$, and the mixture was incubated at $4^{\circ} \mathrm{C}$ for $18 \mathrm{~h}$. Bound tracer was separated by precipitation with goat anti-rabbit serum and normal rabbit serum. The supernatant was aspirated, and the radioactivity in the pellet was determined by a gamma counter.

\section{Western Blot}

To perform protein extraction, we thawed and homogenized frozen lungs or cells in three volumes of lysis buffer [10 mM Tris ( $\mathrm{pH} 7.4)$, $150 \mathrm{mM} \mathrm{NaCl}, 1 \%$ Triton $\mathrm{X}-100,1 \%$ sodium deoxicolate, $0.1 \%$ SDS, and $5 \mathrm{mM}$ EDTA] containing a protease inhibitor cocktail, using a Polytron homogenizer. The homogenate was clarified by centrifugation, and the final protein concentration was determined. Forty micrograms of protein per sample were heated at $70^{\circ} \mathrm{C}$ for $10 \mathrm{~min}$ and then electophoretically separated in a gradient NuPage $4-12 \%$ BisTris gel (Invitrogen) for $30 \mathrm{~min}$ under reducing (5\% 2-mercaptoethanol) conditions. Transfer blotting onto polyvinylidene difluoride membranes was accomplished at $30 \mathrm{~V}$ for $1 \mathrm{~h}$. Membranes were subsequently blocked in 5\% defatted milk-PBS for $1 \mathrm{~h}$ and incubated overnight at $4^{\circ} \mathrm{C}$ with a primary rabbit antiserum directed to the synthetic peptide P072 (amidated $\mathrm{ADM}_{22-52}$ ) diluted 1:1,000 or with a mouse anti- $\beta$-actin antibody (Sigma) diluted 1:5,000. Characterization of the anti-ADM antiserum was reported previously (22). Blots were then incubated with the correspondent horseradish peroxidaselinked secondary antibodies (1:5,000; Amersham Pharmacia Biotech) and developed with Western blot Luminol Reagent kit (Santa Cruz Biotechnology, Santa Cruz, CA). $\beta$-Actin-immunoreactive bands were used as an internal loading control. Adsorption controls for ADM were performed using the ADM antiserum at 1:1,000 preincubated with $10 \mu \mathrm{M}$ of amidated $\mathrm{ADM}_{22-52}\left(4^{\circ} \mathrm{C}\right.$ overnight $)$.

\section{Statistical Methods}

For each time point, the experimental design (LPS being present or absent and normoxia or hypoxia) conformed to a $2 \times 2$ table, and these data were analyzed by a two-way ANOVA, if the hypotheses of normality and equal variance were rejected, to investigate the possible interactions (synergism) between both factors: hypoxia and LPS. If interactions between the concentration of oxygen and LPS treatment were found, nonorthogonal comparisons with the Bonferroni adjustment were performed. Because animals died after $24 \mathrm{~h}$ in the hypoxia + LPS treatment, data were analyzed by one-way ANOVA for this time point. Similarly, if the hypothesis of homogeneity of variances was rejected, one-way ANOVA with factorial treatments was applied (SPSS, Chicago, IL). Values are expressed as the means \pm $\mathrm{SD}$, and statistical significance was defined as $P<0.05$.

\section{RESULTS}

\section{In Vivo Model}

Assessment of lung permeability to protein after different treatments. To determine whether treatments of hypoxia, LPS, or hypoxia + LPS induced pulmonary vascular injury, extravasation of intravascular protein was measured with FITC-labeled BSA. Compared with the control group, the permeability index was found to increase significantly only after the hypoxia + LPS treatment $(3.75 \pm 0.31, n=4$ vs. $5.57 \pm 1.2, n=4$, respectively; $P=0.0034)$. Immunohistochemical detection of FITC in lung sections revealed weak positivity in rat lungs treated with hypoxia or LPS alone (Fig. $1, B$ and $C$ ). However, FITC immunostaining was greatly increased in the perivascular space and in alveolar macrophages of lungs from animals treated with hypoxia + LPS (Fig. 1, $D-F$ ). Therefore, in contrast to the other experimental conditions, only the hypoxia + LPS treatment seems to induce pulmonary vascular injury as determined by extravasation of albumin results.

ADM mRNA levels in rat lungs. Northern analysis for ADM expression in rat lung demonstrated a consistent increase in its mRNA induced by hypoxia, LPS, and hypoxia + LPS treatments (Fig. 2). A synergistic effect in the upregulation of ADM mRNA could be observed between hypoxia and LPS, with a significant increase in the expression of ADM mRNA in lungs of rats exposed to the combined treatment compared with the expression after each treatment alone (Fig. 2A). This interaction (synergism) in the combined treatment was found to be statistically significant at $6(P=0.003)$ and $12(P<0.001) \mathrm{h}$ of treatment.

ISH on lung sections from control animals showed expression of ADM mRNA in some epithelial cells of bronchioles, the endothelium of blood vessels, some cells of the lung parenchyma, and in alveolar macrophages (Fig. 3, A-C). After hypoxic exposure alone, there was an increase in the number of positive bronchiolar cells and cells of the lung parenchyma, and endothelial cells showed a more intense staining (Fig. 3, $D-F$ ). In LPS-treated rat lungs (Fig. 3, $G-I$ ), ADM mRNA expression was found only in inflammatory cells adhering to vascular endothelial cells (Fig. 3I). The combined treatment with hypoxia + LPS (Fig. 3, J-L) caused the highest expression of ADM mRNA, which was localized in bronchiolar epithelial cells, inflammatory-like cells present in blood vessels, and in most cells of the lung parenchyma (Fig. $3 K$ ). Absence of staining using the sense riboprobe demonstrated the specificity of the technique (Figs. 4, $A$ and $B$ ).

$A D M$ protein expression. Western blot analysis of rat lung extracts revealed five immunoreactive bands for ADM and its precursor species with approximate molecular masses of 22, $18,15,13$, and $6 \mathrm{kDa}$ (Fig. 4C), as described previously (15). 

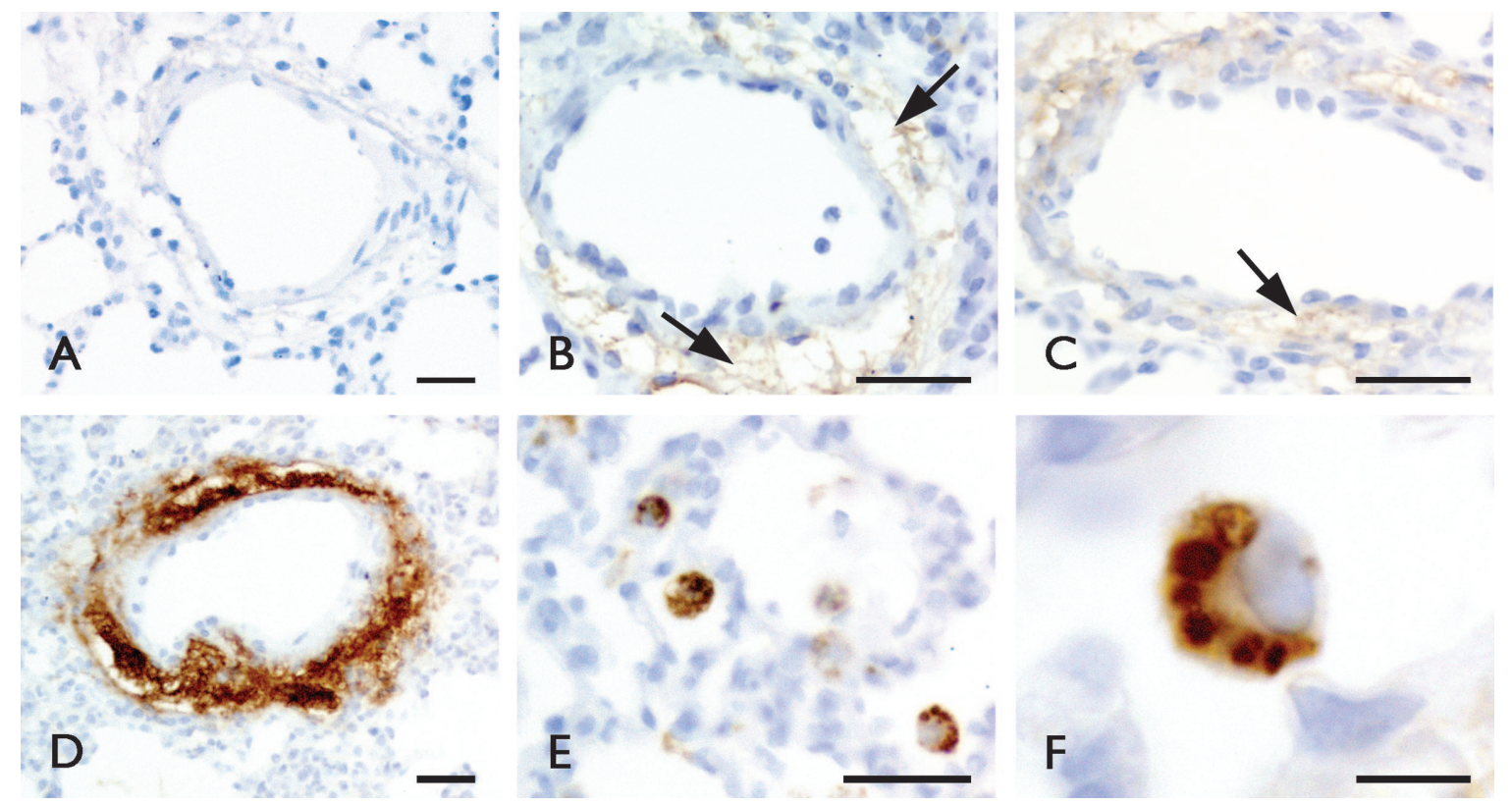

Fig. 1. Permeability to albumin was assessed by immunolocalization of FITC. In control lungs (A), no detectable immunostaining for FITC is found. In rat lungs treated with hypoxia $(B)$ or LPS $(C)$, slight immunoreactivity is observed in the perivascular space (arrows). After the hypoxia + LPS treatment ( $D-F$ ), FITC-albumin is highly accumulated in the perivascular space $(D)$ and phagocyted by alveolar macrophages $(E$ and $F)$. Bars: $30 \mu \mathrm{m}(A-E), 6 \mu \mathrm{m}(F)$.

\section{A}

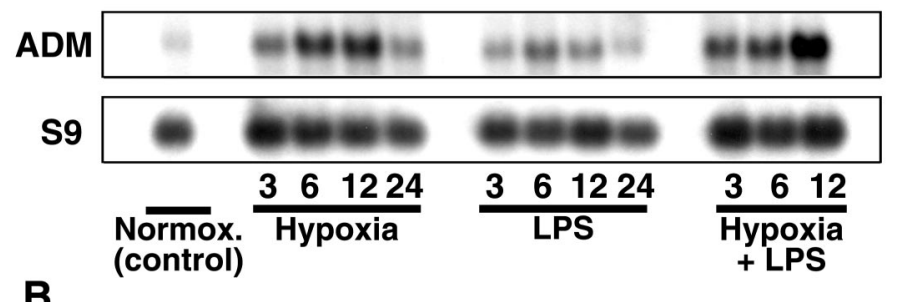

B

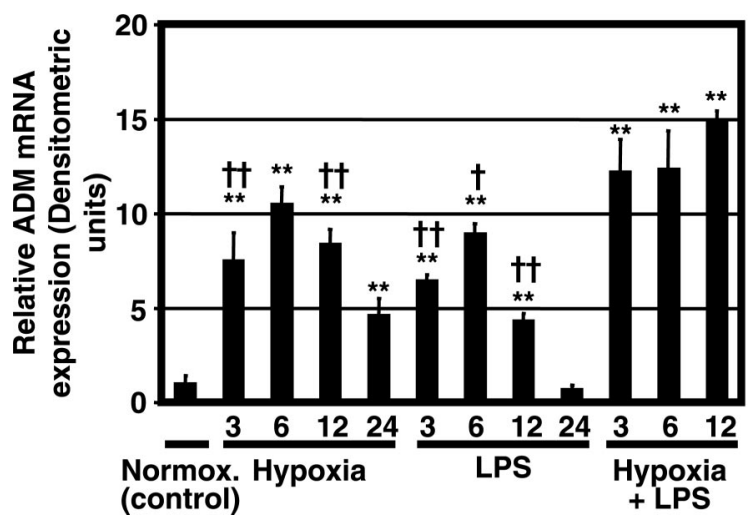

Fig. 2. Northern blot analysis of adrenomedullin (ADM) in rat lungs. $A$ : representative Northern blot analysis of ADM and S9 mRNA from lung extracts of rats exposed to normoxia $\left(20 \% \mathrm{O}_{2}\right)$ or hypoxia $\left(9 \% \mathrm{O}_{2}\right)$ and injected with saline or LPS $(0.1 \mathrm{mg} / \mathrm{kg})$ for $3,6,12$, and $24 \mathrm{~h}$. Combined treatment of hypoxia and LPS was lethal at $24 \mathrm{~h}$ of exposure. Fifteen micrograms of total RNA were loaded per lane. $B$ : quantitation of ADM mRNA levels normalized to the signal for S9 mRNA. To standardize between experiments, we assigned an arbitrary density of 1 to the band obtained from lungs of rats exposed to normoxia. Values are expressed as means $\pm \mathrm{SD}$ (bars) $(n=4$ for each group at each time point). ${ }^{* *} P<0.01$ compared with the control group; $\uparrow P<0.05$, $\dagger \dagger P<0.01$ compared with the hypoxia + LPS group.
Only the 6-kDa band, corresponding to the fully processed ADM, changed its intensity along with the different treatments, while the area and intensity of the rest of the immunoreactive bands remained constant. Therefore, we focused our analysis on the changes observed for the fully processed ADM peptide. Adsorption controls of the antiserum against ADM with the amidated $\mathrm{ADM}_{22-52}$ peptide showed no immunoreactive bands (Fig. 4C).

Hypoxia and LPS treatments alone elicited an increase in ADM expression compared with the signal in the control group (Fig. 5). In accordance with the Northern blot results, the combined treatment of hypoxia and LPS further increased ADM production compared with either treatment alone, suggesting a synergistic interaction of both treatments (Fig. 5). In fact, a significant interaction between LPS and oxygen concentration was found at $3(P<0.001), 6(P=0.009)$, and 12 $(P=0.036) \mathrm{h}$ of treatment.

\section{In Vitro Model}

ADM expression in cell lines. Rat lung type II epithelial cells (CCL-149), RPMVEC, and rat alveolar macrophages (CRL2192) were exposed to normoxia or hypoxia for $0.5,1,3,6,12$, or $24 \mathrm{~h}$ (Northern blot analysis) or 12, 24, or $48 \mathrm{~h}$ (RIA of the conditioned medium) and concomitantly treated with or without LPS. The study of ADM mRNA expression (Northern blot) and secreted peptide (RIA) revealed different responses according to cell type. Epithelial (Fig. 6) and endothelial (Fig. 7) cell lines developed a similar pattern of ADM expression and secretion in response to the treatments. Treatment with LPS in normoxic conditions in these two cell types did not significantly modify ADM expression and secretion compared with the control group (Figs. 6 and 7). However, hypoxia and hypoxia + LPS treatments resulted in an equivalent and strong induction of ADM gene expression and secretion into the conditioned media in both cell types. 


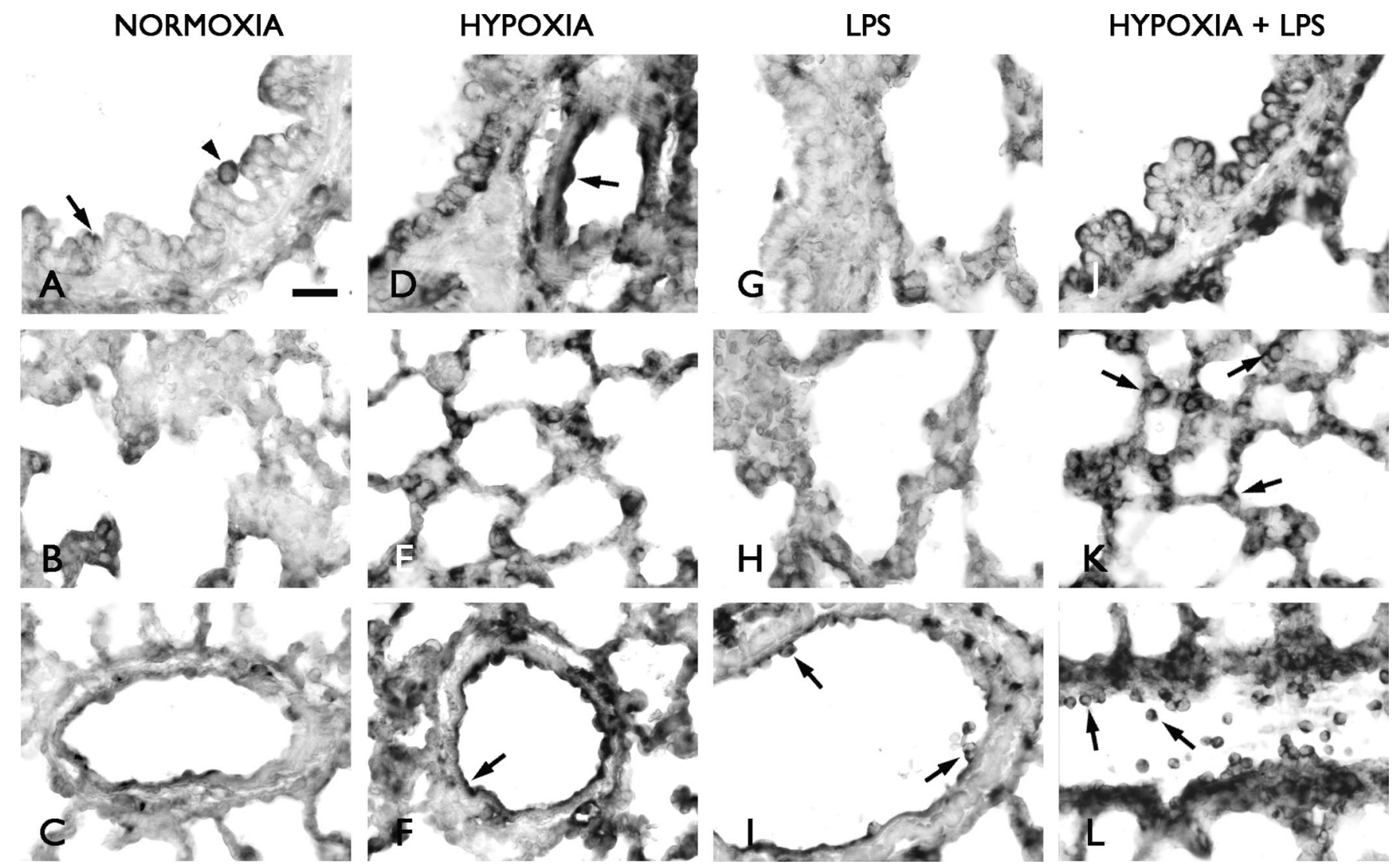

Fig. 3. In situ hybridization (ISH) for ADM mRNA in rat lungs after $3 \mathrm{~h}$ of treatment. ISH performed with the antisense riboprobe in normoxia-treated rat lungs $(A-C)$ shows expression of ADM mRNA in the apical region of some epithelial cells of bronchioles (arrow, $A$ ), alveolar macrophages (arrowhead, $A$ ), some cells of lung parenchyma $(B)$, and endothelium of blood vessels $(C)$. In hypoxia-treated lungs, ADM mRNA is strongly expressed in most bronchiolar epithelial cells $(D)$, and in higher numbers of parenchymal $(E)$ and endothelial cells (arrows, $D$ and $F$ ) than in control lungs. After LPS treatment $(G-I)$, no differences are found with respect to the control group in bronchioles $(G)$ and parenchyma $(H)$, although numerous positive cells are found within blood vessels, most of which adhered to the endothelium (arrows, $I$ ). In hypoxia + LPS-treated lungs $(J-L)$, ISH with the antisense riboprobe shows an important increase of ADM mRNA expression in bronchiolar $(J)$ and parenchymal (arrows, $K$ ) cells. Additionally, numerous positive cells are found within blood vessels $(\operatorname{arrows}, L$ ). Bar $=30 \mu m$ (magnification is equivalent for every micrograph in Fig. 4).

In the rat alveolar macrophage cell line, ADM mRNA signal was barely detectable in cells exposed to normoxia or hypoxia (Fig. 8A). However, treatment with LPS resulted in a significant induction of ADM gene expression, which was further increased with the combined treatment of hypoxia + LPS (Fig. $8, A$ and $B)$. Nevertheless, very low levels of secreted ADM in the culture media were found by RIA analyses, with no significant differences between groups (Fig. 8C). To explore possible causes for the low ADM secretion levels in this cell line, we performed experiments based on the addition of exogenous ADM to the conditioned media with or without protease inhibitors (5 mM EDTA and $0.5 \mathrm{mM} 1,10$ phenanthroline). Data in Fig. $8 D$ suggest that ADM is being degraded in the conditioned media of macrophages exposed to the four experimental groups. Compared with the control group, the degradation rate of ADM was greater in the hypoxia, LPS, and hypoxia + LPS groups and was prevented by the addition of EDTA or 1,10 phenanthroline (Fig. $8 D$ ). Although direct addition of 1,10 phenanthroline to the macrophages at the beginning of the experimental treatments considerably affected cell viability (cell death $40 \pm 5 \%$ ), secreted ADM was detectable in all the conditioned media, with the hypoxia + LPS treatment showing a significant increase compared with the control group (Fig. 8E).

\section{DISCUSSION}

The pathological features used to characterize ALI and ARDS are increased permeability of the alveolar capillary membrane, accumulation of edema, and severe hypoxemia (2). This pathological process is typically described through three overlapping phases (40). The acute (inflammatory) phase (usually develops the first week after the onset of the disorder) is characterized by a rise in permeability of the alveolar-capillary barrier and the influx of protein-rich edema. There is also an increase in margination of pulmonary leukocytes, which together with alveolar macrophages, secrete numerous pro- and anti-inflammatory mediators. The acute phase is followed by the proliferative stage, which is essentially characterized sequentially by organization of exudates and fibrosis of the alveolar spaces. Finally, in the fibrotic phase there is progression of the fibrotic lung injury, which involves the reduction of lung compliance and impaired gas exchange. As previously described (1), histological examination of the present rat model showed a considerable rise in the number of inflammatory cells (monocytes, neutrophils, and lymphocytes) migrating to the lung in LPS-treated rats compared with rats treated with normoxia or hypoxia. The number of inflammatory cells was further increased when treatment with LPS was combined with 

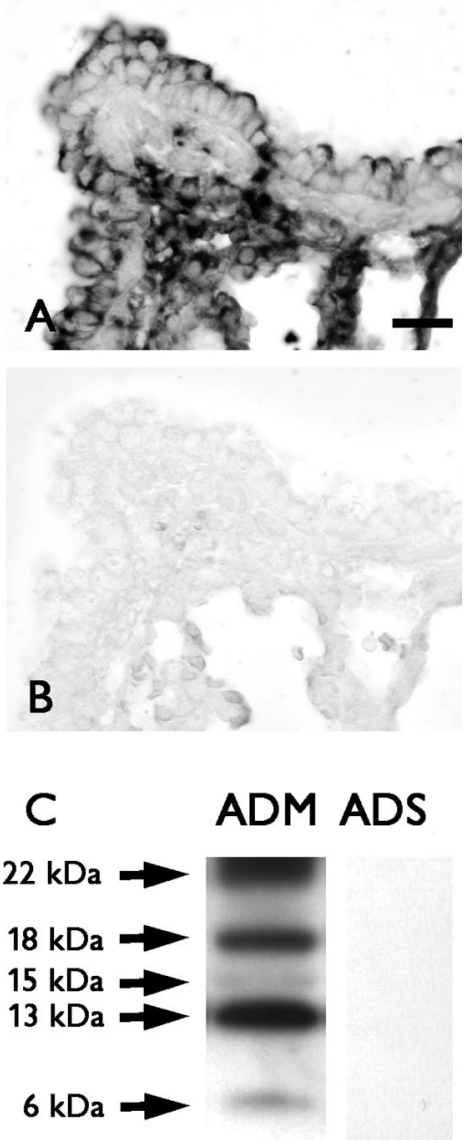

Fig. 4. Negative controls for ISH and Western blot techniques. Serial sections of rat lung treated with hypoxia + LPS for $3 \mathrm{~h}$ and hybridized with the antisense $(A)$ or sense $(B)$ riboprobe for rat ADM. Note the absence of labeling when hybridization is performed with the sense riboprobe. Bar $=30 \mu \mathrm{m}$. $C$ : Western blot for ADM in homogenates of rat lungs treated with hypoxia + LPS for $6 \mathrm{~h}$. Five ADM-immunoreactive bands, including the mature peptide (6 kDa) can be observed. Adsorption control (ADS) lacks immunoreactivity.

the concomitant exposure to hypoxia. In addition, the combination of hypoxia and LPS treatments was also characterized by a significant increase in wet-to-dry lung weight ratio compared with the other experimental conditions, which is consistent with the pulmonary vascular injury observed in clinical ALI (1). The present data on extravasation of FITC-albumin shown both by permeability index determination and by immunocytochemical localization of FITC add further evidence to support the relevance of the hypoxia + LPS treatment as a good experimental model that seems to mimic the acute (inflammatory) phase of ALI.

Various studies have demonstrated elevated plasma levels of ADM in animal models of ALI and in patients with SIRS (20). In these studies, plasma ADM levels positively correlated with the severity of ARDS (39). The increased production and release of ADM in ARDS and other stress-associated pathologies have been considered as having a protective role during the inflammatory response (7). In relation to this, Shindo et al. (34), using transgenic mice overexpressing ADM in their vasculature, have demonstrated the protective role of ADM against circulatory collapse, organ damage, and mortality characteristic of endotoxic shock. Furthermore, the combined ad- ministration of ADM and the complement component factor $\mathrm{H}$, an ADM binding protein, attenuated tissue injury and reduced the mortality rate in the cecal ligation and puncture rat model of sepsis (42). Specifically, in experimental ALI/ARDS conditions, elevated plasma and lung levels of ADM have been proposed to perform its beneficial role mainly by two complementary mechanisms: firstly, reducing endothelial hyperpermeability by cAMP-dependent relaxation of the endothelial microfilament system and thus reducing edema formation (11), and secondly, ensuring myocardial performance through its vasodilatory effects counteracting those of endothelin-1 from the lung (36).

ADM has been found to be upregulated by hypoxia and LPS, two key factors involved in ALI, both in vivo (12) and in vitro (26). In the present work we have analyzed the expression of $\mathrm{ADM}$ by a variety of biochemical and molecular techniques in a rat experimental model of ALI that combines hypoxia and LPS stimuli. In parallel, we have performed in situ techniques to identify which cell types in the lung are involved in the synthesis and release of ADM. Our results show that acute hypoxia and LPS treatments alone induce ADM expression (mRNA and protein) in rat lung as reported previously $(12,24)$. ISH techniques in the lungs of rats exposed to hypoxia showed that, apart from endothelial cells (41), upregulation of ADM mRNA is further localized in epithelial cells of bronchioles and cells in the parenchyma. In the LPS-treated group, besides endothelial cells (24), a large number of inflammatory cells within blood vessels are the main source of ADM mRNA overexpression. Interestingly, when hypoxia and LPS stimuli

\section{A}

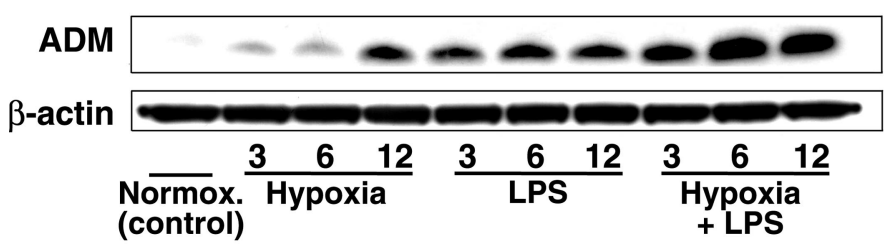

B

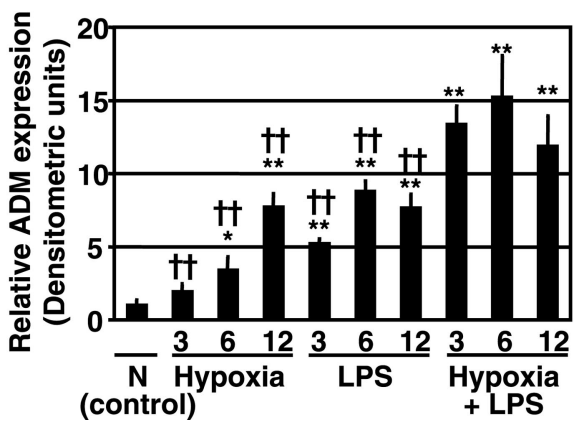

Fig. 5. Western blot for lung mature ADM expression. A: representative immunoblot of lung fully processed $\mathrm{ADM}(6 \mathrm{kDa}$ band) and $\beta$-actin protein content of normoxic and hypoxic rats injected with saline or LPS $(0.1 \mathrm{mg} / \mathrm{kg})$ for 3, 6, and 12 h. $B$ : densitometric analysis of ADM expression (6-kDa band) with different treatment and times of exposure is shown as the ratio of ADM to $\beta$-actin signals for each sample. An arbitrary density of 1 was assigned to the band obtained from lungs of rats exposed to normoxia $(\mathrm{N})$ to standardize between experiments. Data shown as means \pm SD (bars) $(n=4$ for each group at each time point) $* P<0.05, * * P<0.01$ compared with the control group; $\dagger \uparrow P<0.01$ compared with the hypoxia + LPS group. 
A

Fig. 6. Expression of ADM in the CCL-149 epithelial cell line. A: representative Northern blot analysis for ADM mRNA expression. $B$ : relative ADM mRNA expression after $12 \mathrm{~h}$ of treatment normalizing ADM densitometric values to those of S9 for each sample. Standardization between experiments was accomplished assigning an arbitrary density of 1 to the signal obtained from cells exposed to normoxia. N, normoxia; $\mathrm{H}$, hypoxia. $C$ : ADM peptide in the conditioned media measured by RIA. Values are expressed as means $\pm \mathrm{SD}$ (bars) $(n=3$ for each group). $* P<0.05$, $* * P<0.01$ compared with the control group; $\dagger \uparrow P<0.01$ compared with the hypoxia + LPS group.
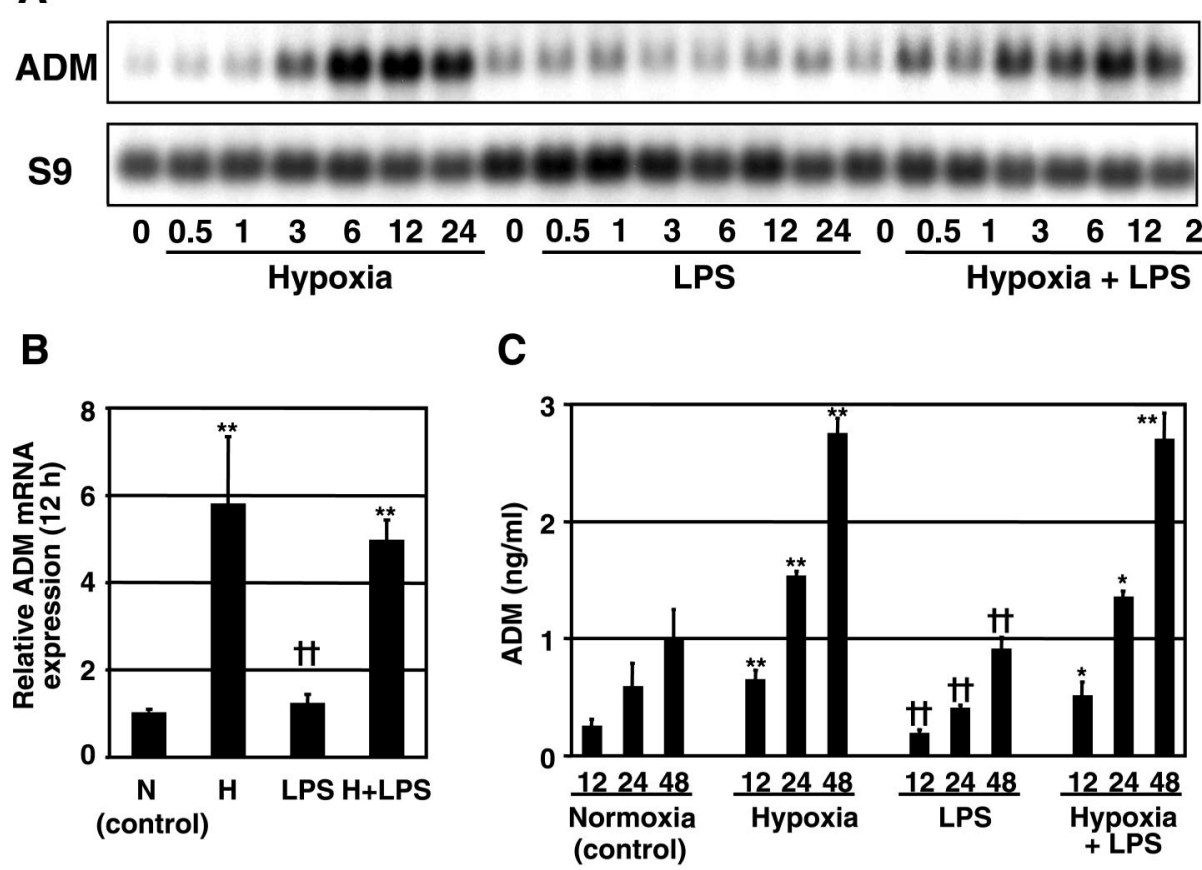

are combined, ADM expression (mRNA and protein) is synergistically induced in rat lungs. As demonstrated by ISH in the combined treatment, the cells mostly responsible for this increase in ADM mRNA expression in the lungs are numerous inflammatory cells within blood vessels; to a lesser extent, also cells and in the lung parenchyma and epithelial cells in bronchioles and alveoli account for the upregulated ADM synthesis. Our results demonstrate that ADM is greatly overexpressed in this experimental model of the inflammatory phase of ALI, suggesting that this peptide may play a relevant role in this syndrome, although more studies are needed to describe the precise role of ADM in ALI. Moreover, our data point to the lungs as a likely contributing source of the elevated ADM plasma levels occurring in ALI patients.

ADM biology is closely related to nitric oxide synthase-2 (NOS2) and the NO cascade. NO has been shown to stimulate ADM production in endothelial and smooth muscle cell lines $(6,13)$. Furthermore, in transgenic mice overexpressing ADM in their vasculature, NO production is highly augmented (34). Both ADM and NO share diverse physiological functions that
Fig. 7. Expression of ADM in the RPMVEC endothelial cell line. $A$ : representative Northern blot analysis for ADM mRNA. $B$ : relative ADM mRNA expression after $12 \mathrm{~h}$ of treatment expressed as the ratio of ADM to S9 mRNA densitometric values. To standardize between experiments, an arbitrary density of 1 was assigned to the band obtained from cells exposed to normoxia. $C$ : ADM peptide in the conditioned media by RIA analysis. Values are expressed as means $\pm \mathrm{SD}$ (bars) $(n=3$ for each group). $* P<0.05, * * P<0.01$ compared with the control group; $\dagger \dagger P<0.01$ compared with the hypoxia + LPS group.
A
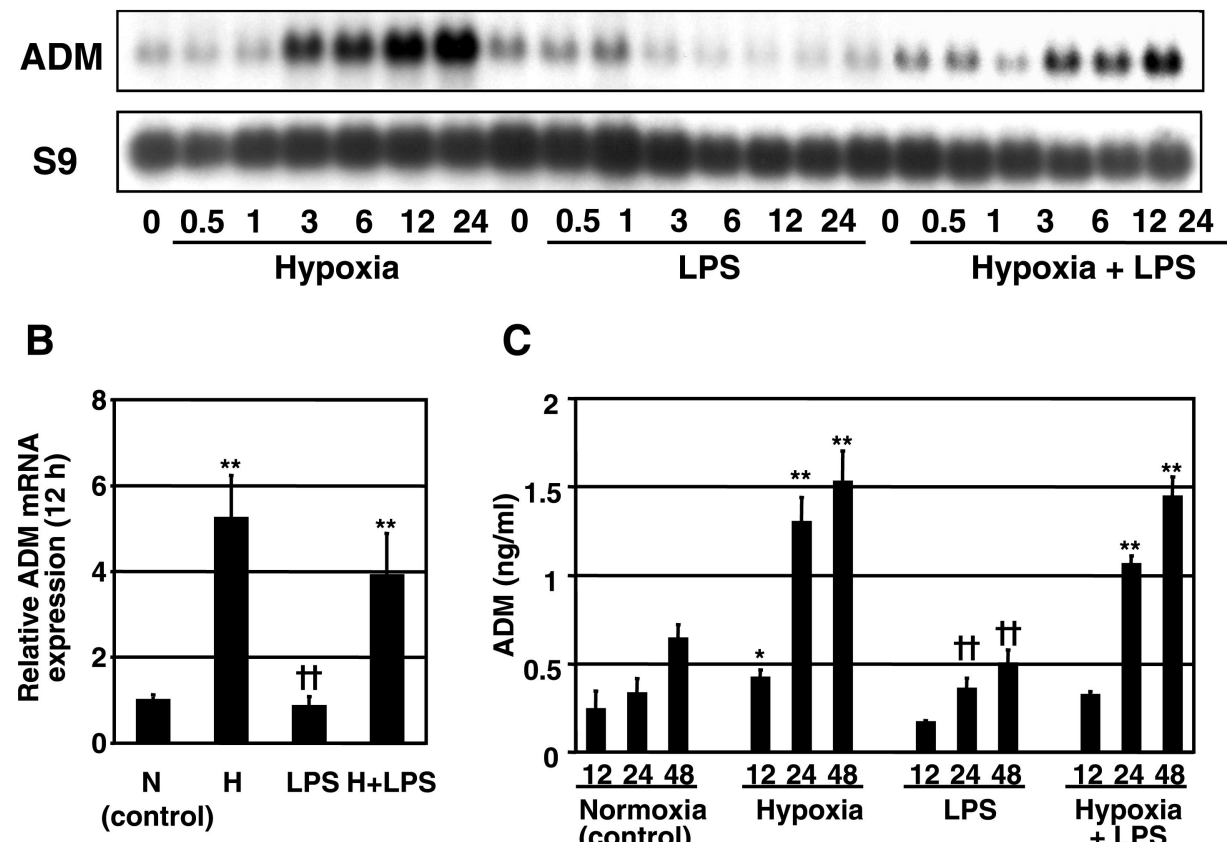

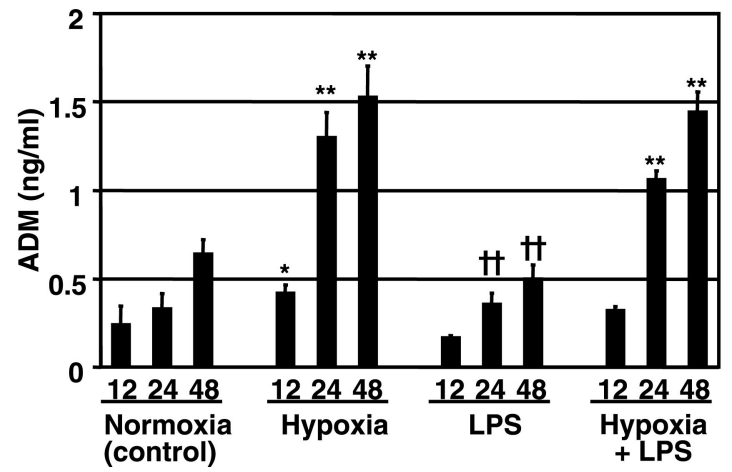


A

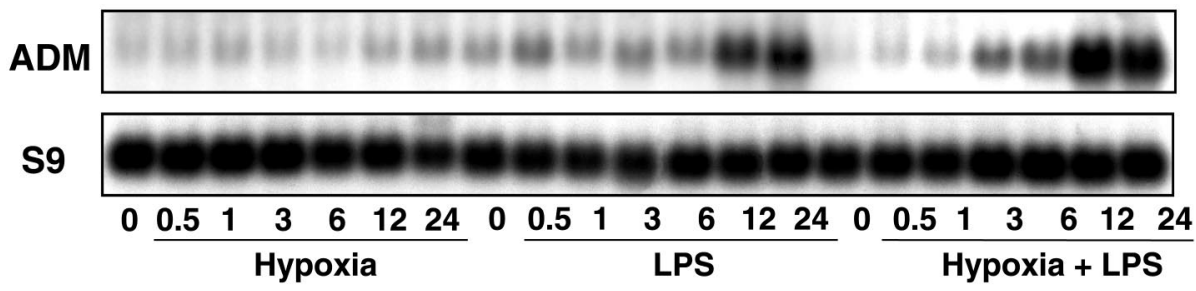

B

C

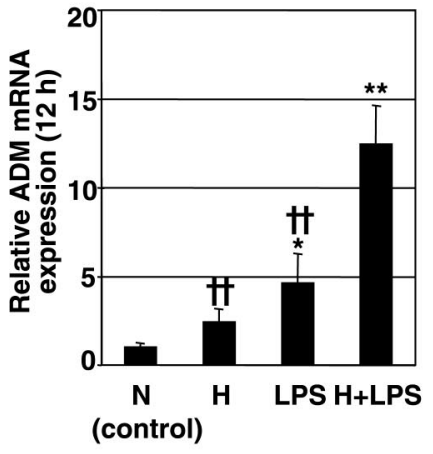

D

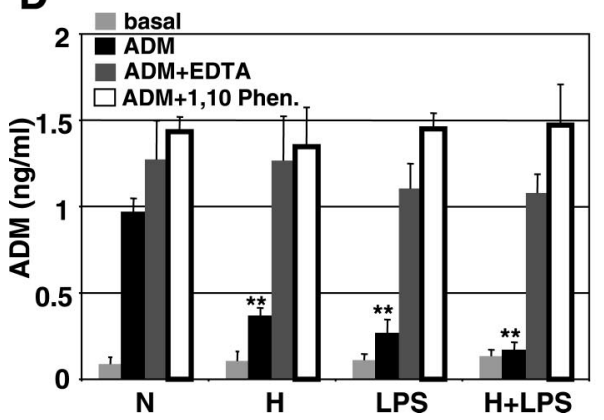

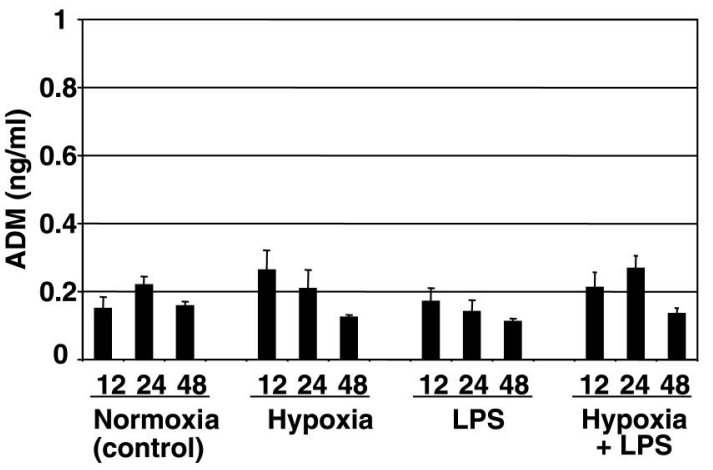

E

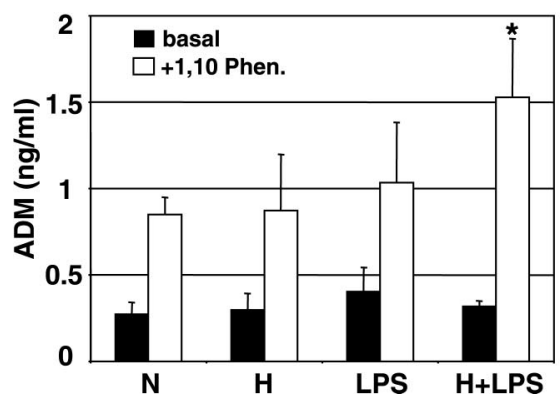

Fig. 8. Expression of ADM in the CRL-2192 alveolar macrophage cell line. $A$ : representative Northern blot analysis for ADM. B: relative ADM mRNA expression after $12 \mathrm{~h}$ of treatment as the ratio of ADM to S9 mRNA densitometric values. To standardize between experiments, an arbitrary density of 1 was assigned to the value correspondent to cells exposed to normoxia. $C$ : rat $\mathrm{ADM}$ peptide in the conditioned media by RIA analysis. D: ADM concentration was assessed by RIA analysis. The conditioned media of macrophages exposed to $24 \mathrm{~h}$ of treatment were incubated with exogenously added ADM $(1.28 \mathrm{ng} / \mathrm{ml})$ for $24 \mathrm{~h}$ at $37^{\circ} \mathrm{C}$, together with 5 mM EDTA (dark gray bars) or $0.5 \mathrm{mM} 1,10$ phenanthroline (Phen., open bars) or absence of protease inhibitors (closed bars). Initial ADM content in the conditioned media (previous to ADM addition) is represented as light gray bars. $E$ : RIA analysis of rat ADM in the conditioned media of macrophages treated with (open bars) or without (closed bars) $0.5 \mathrm{mM} \mathrm{1,10} \mathrm{Phen.} \mathrm{at}$ the beginning of a 24-h exposure to each experimental condition. Values are expressed as means $\pm \mathrm{SD}$ (bars) $(n=3$ for each group). $* P<0.05, * * P<0.01$ compared with the normoxia group; $\dagger \dagger P<0.01$ compared with the hypoxia + LPS group. include vasodilation, bronchodilation, and antimicrobial activity. A previous study from our laboratory reported an increase in the expression of NOS2 in the present model of ALI and the involvement of inflammatory cells in this event (1). In this animal model of ALI, ADM and NO appear to be upregulated in a coordinated fashion that may possibly be related to a cooperative role in the control of the inflammatory response.

In accordance with the animal model, a differential regulation of ADM expression in the three rat lung cell types studied (endothelial, type II epithelial cells, and alveolar macrophages) was found in our in vitro studies. Endothelial and epithelial cells showed basal detectable levels of ADM (mRNA and protein) in normoxic conditions. In the same way, ADM expression had been observed previously in endothelial cells from different species and types of blood vessels $(26,37)$. Also, ADM and its receptor L1 have been found in human type II pneumocytes (21) and have been correlated with increased secretion of phosphatidylcholine, the predominant component of pulmonary surfactant (31). After LPS treatment, ADM expression in epithelial and endothelial cells was similar to that in the control group. In the type II epithelial cell line (CCL149), this finding was not surprising since we did not find expression of Toll-like receptor 4 (TLR4), the main receptor of
LPS by RT-PCR techniques (data not shown). Concerning the endothelial RPMVEC cells, previous studies report that ADM expression in endothelial cells in response to LPS varies greatly in endothelial cells from different origins (37). Although RPMVEC express TLR4 mRNA (RT-PCR data not shown), it has been previously reported that a combination of LPS and cytokines is needed to induce NOS 2 expression in this cell line (43). It is probable, therefore, that combination of LPS with other stimuli might also be needed for ADM induction in RPMVEC. Concerning hypoxic conditions, a clear induction of ADM expression and secretion was found in the epithelial and endothelial cell lines studied herein, as we and others previously reported in epithelial cells from different sources $(8,38)$ and endothelial cells (26). When we subjected epithelial and endothelial cells to a combined treatment of hypoxia and LPS, the expression and secretion of ADM were similar to that obtained after exposure to hypoxia alone. This seems to correlate with the absence of ADM induction by treatment with LPS, indicating that in both cell lines, only the hypoxic stimulus induces the expression and secretion of ADM.

Other authors have shown basal ADM gene expression and release in macrophages and their related cells $(18,27)$, particularly in alveolar macrophages (28). In the present study, the 
expression of ADM mRNA in the rat alveolar macrophage cell line (CRL-2192) after hypoxic exposure was similar to that in normoxic conditions, although a great overexpression of ADM transcripts was assessed after LPS treatment. The stimulatory effect of LPS on ADM expression and secretion has also been observed in monocyte-derived macrophages and in the mouse peritoneal macrophage-derived RAW 264.7 cell line $(18,27)$. On the other hand, in relation to hypoxic stimulation and in agreement with our results, it has been reported that hypoxic exposure alone does not induce ADM expression in human peritoneal macrophages unless proceeding from cirrhotic patients (4). After the simultaneous exposure to hypoxia and LPS, we found that ADM mRNA expression was even greater than in macrophages treated with LPS and exposed to normoxia, showing a synergistic effect between both stimuli. Despite this, RIA analyses of conditioned media from the CRL-2192 cell line showed no differences in the secretion of ADM peptide among the four experimental groups. In this regard, degradation of exogenously added ADM has been reported when incubated with lung, adrenal, and kidney tissue extracts (19). Besides, this degradation was prevented by addition of EDTA or phenanthroline (19) [a selective inhibitor of metalloproteinases (MP) (33)]. Moreover, it is also known that rat alveolar macrophages produce a wide spectrum of MP (9) and that exposure to different stimuli such as hypoxia (3) or LPS (9) upregulates the expression of MP in this cell type. This background led us to design different experiments to test the hypothesis that secreted ADM was being degraded in the culture media by the parallelly secreted MP. This hypothesis was corroborated since exogenously added ADM degradation was mainly shown after hypoxia, LPS, and hypoxia + LPS treatments, and ADM degradation could be prevented by the addition of protease inhibitors (EDTA and phenanthroline) to the culture media (Fig. 8, D and E). Moreover, although cell viability was compromised, when phenanthroline was directly added to CRL-2192 cells, ADM degradation could be partially abrogated, and a significant increase in ADM in the culture medium was found after the combined treatment compared with the control group. The present study demonstrates that in rat alveolar macrophages, the combined treatment of hypoxia and LPS greatly induces the expression of ADM mRNA as well as the secretion of the mature peptide, thus paralleling the synergistic interaction of both factors observed in the in vivo model. This response in alveolar macrophages is presumably mediated by the hypoxia inducible transcription factor- $1 \alpha$, which has been found to be essential in macrophage response to hypoxia and inflammation (5). Further studies are needed to elucidate whether the ADM secreted by alveolar macrophages might subsequently be degraded by concomitantly secreted MP in ALI conditions. One might as well hypothesize that ADM peptide degradation by macrophage-derived proteases could also constitute a mechanism to regulate ADM levels, since the lung has been shown to be the main clearance organ for this peptide (29).

In summary, ADM expression is highly induced in the present rat model of ALI that combines exposure to hypoxia and treatment with LPS. In addition, there is a good correspondence between our findings in the in vitro experiments and the data obtained in the in vivo model. In this regard, hypoxic exposure induces ADM expression in endothelial and epithelial cells in both models, whereas LPS treatment per se does not have any inductor effect on ADM production in these cell types. In response to the hypoxia + LPS combined treatment, ADM expression is induced in a variety of key cell types such as alveolar macrophages and endothelial and epithelial cells, although the effects in other cell types, such as other inflammatory cells and type I pneumocytes, deserves further in vitro studies.

\section{ACKNOWLEDGMENTS}

The authors thank Dr. Rubén Pío (Div. of Oncology, Center for Applied Medical Research, University of Navarra) for help with radioimmunoassay. We are also grateful to Paz Zamora and Silvia González (Dept. of Histology and Pathology, University of Navarra) for assistance with histological techniques.

\section{GRANTS}

This work was supported by Spanish Ministry of Health Grants FIS 00/0698 and RTIC 03/10 and the UTE project Center for Applied Medical Research.

\section{REFERENCES}

1. Agorreta J, Garayoa M, Montuenga LM, and Zulueta JJ. Effects of acute hypoxia and lipopolysaccharide on nitric oxide synthase-2 expression in acute lung injury. Am J Respir Crit Care Med 168: 287-296, 2003.

2. Bernard GR, Artigas A, Brigham KL, Carlet J, Falke K, Hudson L, Lamy M, Legall JR, Morris A, and Spragg R. The American-European Consensus Conference on ARDS. Definitions, mechanisms, relevant outcomes, and clinical trial coordination. Am J Respir Crit Care Med 149: 818-824, 1994.

3. Burke B, Giannoudis A, Corke KP, Gill D, Wells M, Ziegler-Heitbrock $\mathbf{L}$, and Lewis CE. Hypoxia-induced gene expression in human macrophages: implications for ischemic tissues and hypoxia-regulated gene therapy. Am J Pathol 163: 1233-1243, 2003.

4. Cejudo-Martín P, Morales-Ruiz M, Ros J, Navasa M, FernándezVaro G, Fuster J, Rivera F, Arroyo V, Rodes J, and Jiménez W. Hypoxia is an inducer of vasodilator agents in peritoneal macrophages of cirrhotic patients. Hepatology 36: 1172-1179, 2002.

5. Cramer T, Yamanishi Y, Clausen BE, Forster I, Pawlinski R, Mackman N, Haase VH, Jaenisch R, Corr M, Nizet V, Firestein GS, Gerber HP, Ferrara N, and Johnson RS. HIF-1alpha is essential for myeloid cell-mediated inflammation. Cell 112: 645-657, 2003.

6. Dotsch J, Schoof E, Hanze J, Dittrich K, Opherk P, Dumke K, and Rascher W. Nitric oxide stimulates adrenomedullin secretion and gene expression in endothelial cells. Pharmacology 64: 135-139, 2002.

7. Elsasser TH and Kahl S. Adrenomedullin has multiple roles in disease stress: development and remission of the inflammatory response. Microsc Res Tech 57: 120-129, 2002.

8. Garayoa M, Martínez A, Lee S, Pío R, An WG, Neckers L, Trepel J, Montuenga LM, Ryan H, Johnson R, Gassmann M, and Cuttitta F. Hypoxia-inducible factor-1 (HIF-1) up-regulates adrenomedullin expression in human tumor cell lines during oxygen deprivation: a possible promotion mechanism of carcinogenesis. Mol Endocrinol 14: 848-862, 2000 .

9. Gibbs DF, Warner RL, Weiss SJ, Johnson KJ, and Varani J. Characterization of matrix metalloproteinases produced by rat alveolar macrophages. Am J Respir Cell Mol Biol 20: 1136-1144, 1999.

10. Goss CH, Brower RG, Hudson LD, and Rubenfeld GD. Incidence of acute lung injury in the United States. Crit Care Med 31: 1607-1611, 2003.

11. Hippenstiel S, Witzenrath M, Schmeck B, Hocke A, Krisp M, Krull M, Seybold J, Seeger W, Rascher W, Schutte H, and Suttorp N. Adrenomedullin reduces endothelial hyperpermeability. Circ Res 91: $618-625,2002$.

12. Hofbauer KH, Jensen BL, Kurtz A, and Sandner P. Tissue hypoxygenation activates the adrenomedullin system in vivo. Am J Physiol Regul Integr Comp Physiol 278: R513-R519, 2000.

13. Hofbauer KH, Schoof E, Kurtz A, and Sandner P. Inflammatory cytokines stimulate adrenomedullin expression through nitric oxide-dependent and -independent pathways. Hypertension 39: 161-167, 2002.

14. Hotchkiss RS and Karl IE. The pathophysiology and treatment of sepsis. $N$ Engl J Med 348: 138-150, 2003. 
15. Jiménez N, Abasolo I, Jongsma J, Calvo A, Garayoa M, van der Kwast TH, van Steenbrugge GJ, and Montuenga LM. Androgenindependent expression of adrenomedullin and peptidylglycine alphaamidating monooxygenase in human prostatic carcinoma. Mol Carcinog 38: 14-24, 2003.

16. Kitamura K, Kangawa K, Kawamoto M, Ichiki Y, Nakamura S, Matsuo H, and Eto T. Adrenomedullin: a novel hypotensive peptide isolated from human pheochromocytoma. Biochem Biophys Res Commun 192: 553-560, 1993.

17. Krinke GJ. The Laboratory Rat. San Diego, CA: Academic, 2000.

18. Kubo A, Minamino N, Isumi Y, Katafuchi T, Kangawa K, Dohi K, and Matsuo H. Production of adrenomedullin in macrophage cell line and peritoneal macrophage. J Biol Chem 273: 16730-16738, 1998.

19. Lewis LK, Smith MW, Brennan SO, Yandle TG, Richards AM, and Nicholls MG. Degradation of human adrenomedullin(1-52) by plasma membrane enzymes and identification of metabolites. Peptides 18: 733 739, 1997.

20. López J and Martínez A. Cell and molecular biology of the multifunctional peptide, adrenomedullin. Int Rev Cytol 221: 1-92, 2002.

21. Martínez A, Miller MJ, Catt KJ, and Cuttitta F. Adrenomedullin receptor expression in human lung and in pulmonary tumors. J Histochem Cytochem 45: 159-164, 1997.

22. Martínez A, Miller MJ, Unsworth EJ, Siegfried JM, and Cuttitta F. Expression of adrenomedullin in normal human lung and in pulmonary tumors. Endocrinology 136: 4099-4105, 1995.

23. Martínez A, Saldise L, Ramírez MJ, Belzunegui S, Zudaire E, Luquin MR, and Cuttitta F. Adrenomedullin expression and function in the rat carotid body. J Endocrinol 176: 95-102, 2003.

24. Matsui E, Kitamura K, Yoshida M, Kato J, Asada Y, Sumiyoshi A, and Eto T. Biosynthesis and secretion of adrenomedullin and proadrenomedullin N-terminal 20 peptide in a rat model of endotoxin shock. Hypertens Res 24: 543-549, 2001.

25. Matthay MA, Zimmerman GA, Esmon C, Bhattacharya J, Coller B, Doerschuk CM, Floros J, Gimbrone MAJ, Hoffman E, Hubmayr RD, Leppert M, Matalon S, Munford R, Parsons P, Slutsky AS, Tracey KJ, Ward P, Gail DB, and Harabin AL. Future research directions in acute lung injury: summary of a national heart, lung, and blood institute working group. Am J Respir Crit Care Med 167: 1027-1035, 2003.

26. Minamino N, Kikumoto K, and Isumi Y. Regulation of adrenomedullin expression and release. Microsc Res Tech 57: 28-39, 2002.

27. Nakayama M, Takahashi K, Murakami O, Murakami H, Sasano H, Shirato K, and Shibahara S. Adrenomedullin in monocytes and macrophages: possible involvement of macrophage-derived adrenomedullin in atherogenesis. Clin Sci (Colch) 97: 247-251, 1999.

28. Nakayama M, Takahashi K, Murakami O, Yanai M, Sasaki H, Shirato K, and Shibahara S. Production and secretion of adrenomedullin in cultured human alveolar macrophages. Peptides 20: 1123-1125, 1999.

29. Nishikimi T, Matsuoka $\mathbf{H}$, Shimada $\mathbf{K}$, Matsuo $\mathbf{H}$, and Kangawa $\mathbf{K}$. Production and clearance sites of two molecular forms of adrenomedullin in human plasma. Am J Hypertens 13: 1032-1034, 2000.
30. Nuckton TJ, Alonso JA, Kallet RH, Daniel BM, Pittet JF, Eisner MD, and Matthay MA. Pulmonary dead-space fraction as a risk factor for death in the acute respiratory distress syndrome. $N$ Engl J Med 346: 1281-1286, 2002.

31. Okumura M, Kai H, Arimori K, Iwakiri T, Hidaka M, Shiramoto S, Isohama Y, and Miyata T. Adrenomedullin increases phosphatidylcholine secretion in rat type II pneumocytes. Eur J Pharmacol 403: 189-194, 2000 .

32. Riedemann NC, Guo RF, and Ward PA. The enigma of sepsis. J Clin Invest 112: 460-467, 2003.

33. Sawicki G, Salas E, Murat J, Miszta-Lane H, and Radomski MW. Release of gelatinase A during platelet activation mediates aggregation. Nature 386: 616-619, 1997.

34. Shindo T, Kurihara H, Maemura K, Kurihara Y, Kuwaki T, Izumida T, Minamino N, Ju KH, Morita H, Oh-hashi Y, Kumada M, Kangawa K, Nagai R, and Yazaki Y. Hypotension and resistance to lipopolysaccharide-induced shock in transgenic mice overexpressing adrenomedullin in their vasculature. Circulation 101: 2309-2316, 2000.

35. Sievers L and Kugler P. Reabsorption of fluorescein-isothiocyanatelabelled-ovalbumin in the kidney of normal and castrated male and female rats. Histochemistry 86: 215-220, 1986.

36. Stangl K, Laule M, Richter C, Stangl V, Koch J, Goktas O, Baumann G, and Dschietzig T. Pulmonary adrenomedullin counteracts deterioration of coronary flow and myocardial performance evoked by pulmonary endothelins in experimental acute respiratory distress syndrome. Crit Care Med 29: 1027-1032, 2001.

37. Tomoda Y, Isumi Y, Katafuchi T, and Minamino N. Regulation of adrenomedullin secretion from cultured cells. Peptides 22: 1783-1794, 2001.

38. Udono T, Takahashi K, Nakayama M, Yoshinoya A, Totsune K, Murakami O, Durlu YK, Tamai M, and Shibahara S. Induction of adrenomedullin by hypoxia in cultured retinal pigment epithelial cells. Invest Ophthalmol Vis Sci 42: 1080-1086, 2001.

39. Ueda S, Nishio K, Minamino N, Kubo A, Akai Y, Kangawa K, Matsuo H, Fujimura Y, Yoshioka A, Masui K, Doi N, Murao Y, and Miyamoto S. Increased plasma levels of adrenomedullin in patients with systemic inflammatory response syndrome. Am J Respir Crit Care Med 160: 132-136, 1999.

40. Ware LB and Matthay MA. The acute respiratory distress syndrome. N Engl J Med 342: 1334-1349, 2000.

41. Xu P, Dai A, and Zhou H. Expression of adrenomedullin and its receptor in lungs of rats with hypoxia-induced pulmonary hypertension. Zhonghua Jie He He Hu Xi Za Zhi 25: 465-469, 2002.

42. Yang S, Zhou M, Fowler DE, and Wang P. Mechanisms of the beneficial effect of adrenomedullin and adrenomedullin-binding protein-1 in sepsis: down-regulation of proinflammatory cytokines. Crit Care Med 30: 2729-2735, 2002.

43. Zulueta JJ, Sawhney R, Kayyali U, Fogel M, Donaldson C, Huang H, Lanzillo JJ, and Hassoun PM. Modulation of inducible nitric oxide synthase by hypoxia in pulmonary artery endothelial cells. Am J Respir Cell Mol Biol 26: 22-30, 2002. 